\title{
Biological Control of Sclerotinia Stem Rot of Soybean with Sporidesmium sclerotivorum
}

\author{
L. E. del Rio, Department of Plant Pathology, North Dakota State University, Fargo 58105; C. A. Martinson and \\ X. B. Yang, Department of Plant Pathology, Iowa State University, Ames 50011
}

\begin{abstract}
del Rio, L. E., Martinson, C. A., and Yang, X. B. 2002. Biological control of Sclerotinia stem rot of soybean with Sporidesmium sclerotivorum. Plant Dis. 86:999-1004.

Field studies were conducted to evaluate the effectiveness of Sporidesmium sclerotivorum to control Sclerotinia stem rot of soybean (SSR) at Ames, Humboldt, and Kanawha, IA, between 1996 and 1998. Experimental plots $(3 \times 3 \mathrm{~m})$ were infested with $S$. sclerotivorum macroconidia once at a rate of 0,2 , or 20 spores per $\mathrm{cm}^{2}$ in the fall of 1995 or the spring of 1996, under two crop rotation schemes. A randomized complete block design with four replications in each location was used. Plots infested with 20 spores per $\mathrm{cm}^{2}$ had $62 \%$ less SSR $(P=0.05)$ than control plots at Humboldt in 1996. No differences were detected between fall and spring applications. In 1998, plots treated with either 2 or 20 spores per $\mathrm{cm}^{2}$ had 51 to $63 \%$ less SSR $(P=0.05)$ than control plots at Ames and Kanawha. In 1998, SSR was completely suppressed in all plots at Humboldt, while the commercial field surrounding the experimental plots had 17\% SSR. S. sclerotivorum was retrieved from all infested plots at all locations 2 years after infestation with sclerotia of Sclerotinia sclerotiorum as bait. At Humboldt, S. sclerotivorum was also retrieved from control plots. Two larger plots $(10 \times 10 \mathrm{~m})$ were infested with 20 or 100 spores per $\mathrm{cm}^{2}$ in the fall of 1996 or spring of 1997 in six commercial fields. SSR incidence, which was measured in transects up to $20 \mathrm{~m}$ from the infested area at 5-m intervals, was reduced 56 to $100 \%(P=$ $0.05)$ in four fields compared with the surrounding uninfested areas in the commercial fields. Dispersal of the control agent was evident by the fact that SSR incidence gradually increased from the edge of the infested macroplots up to about $10 \mathrm{~m}$ into noninoculated areas of the commercial field. This paper constitutes the first report describing the biocontrol of a disease on field crops that may be employed economically.
\end{abstract}

Sclerotinia stem rot of soybean (SSR), also called white mold of soybean, is incited by the fungus Sclerotinia sclerotiorum (Lib.) de Bary (14). Severe outbreaks of the disease in recent years have placed it as the second most devastating disease of soybean in the United States (30). The reduction in soybean yield due to SSR epidemics represented a loss of more than US\$240 million in 1997 (29).

Sclerotinia sclerotiorum survives in the field by means of sclerotia produced in infected soybean tissues (18). Sclerotia can germinate the following season, producing one to several apothecia (10), or remain dormant for several years (15). Apothecia are produced from sclerotia located in the top $5 \mathrm{~cm}$ of soil, usually after the soybean canopy has closed, when cool to moderate temperatures and high humidity are present for several hours $(11,24)$. Ascospores produced by these apothecia constitute the primary inoculum for infection, which occurs on senescent flowers (18).

Corresponding author: Luis del Rio

E-mail: Luis.delRio-Mendoza@ndsu.nodak.edu

Accepted for publication 15 May 2002.

Publication no. D-2002-0716-02R

(C) 2002 The American Phytopathological Society
Sporidesmium sclerotivorum Uecker, Adams et Ayers is a biotrophic haustorial mycoparasite that attacks the sclerotia of Sclerotinia sclerotiorum and other closely related sclerotial forming plant pathogens $(22,26)$. The potential of $S$. sclerotivorum as a biological control agent for the closely related Sclerotinia minor Jagger has been documented for the control of lettuce drop disease in the laboratory $(2,6)$ and in the field $(4,5)$.

Differences in the epidemiology of lettuce drop and SSR, such as the direct mycelial germination of the sclerotia of Sclerotinia minor (7) versus the production of airborne ascospores for Sclerotinia sclerotiorum $(1,3,28)$, have raised doubts regarding the effectiveness of Sporidesmium sclerotivorum as a biocontrol agent for Sclerotinia sclerotiorum (17). A study that measured the effectiveness of two spore concentrations of $S$. sclerotivorum, delivered either in the fall or the spring, to control Sclerotinia sclerotiorum in soybean planted under two crop rotation systems was established in three Iowa locations. Results of these experiments are presented here.

\section{MATERIALS AND METHODS}

Two types of experiments were performed: multilevel factorial experiments in small, replicated plots, and large macroplots established in soybean-corn rotation fields managed with regular commercial production practices. For both experiments, applications of Sporidesmium sclerotivorum were made in the fall after soybean crops were harvested or in the spring before planting.

Factorial experiments. Factorial experiments were conducted at three Iowa locations: Ames, Humboldt, and Kanawha. Sclerotinia stem rot epidemics had been light and sporadic at Kanawha, heavy at Humboldt, and had not been observed at Ames prior to this study.

Plot preparation. Experimental areas at Ames and Kanawha were chisel-plowed in the fall of 1994 and field cultivated before planting in 1995. In 1995, 48 square plots $(3 \times 3 \mathrm{~m})$ were established and planted to soybean cv. Williams 82 at $19-\mathrm{cm}$ (Ames) or $38-\mathrm{cm}$ (Kanawha) row widths. Each plot was bordered on all sides by a buffer area, $3 \mathrm{~m}$ wide, planted with four rows of corn spaced $76 \mathrm{~cm}$ apart. Sclerotia of Sclerotinia sclerotiorum produced in sunflower fields in 1994 and stored in a warehouse without heating were used to artificially infest them. Each soybean plot was infested with $600 \mathrm{~cm}^{3}$ of sclerotia after planting. At maturity, soybean plants were chopped with a rotary lawnmower. An additional $40 \mathrm{~g}$ of fresh sclerotia (about 400 sclerotia), produced in soybean fields in 1994, was spread over the soybean residue in each plot. Sclerotia were stored in commercial bins with the soybean harvest as seed contaminants.

At Humboldt, 48 experimental plots were established in fall 1995 in a soybean field planted to Williams 82, and with a history of severe SSR infestation. Experimental plots were laid out in the same way as in the other two locations. Soybean residues from the borders were raked into the plots. An additional $40 \mathrm{~g}$ of sclerotia was manually spread in each plot.

Soil $\mathrm{pH}$ (measured in distilled water) at the experimental sites at Ames and Humboldt was an average of $6.7 \pm 0.2$ and $6.3 \pm$ 0.2 , respectively. At the Kanawha site, onehalf of the plots had a soil $\mathrm{pH} 7.0 \pm 0.2$, while the other half had a soil $\mathrm{pH} 6.5 \pm$ 0.2. Replications at the Kanawha site were blocked following the $\mathrm{pH}$ gradient.

Treatments and experimental design. Three factors were investigated: (i) cropping sequence, (ii) amount of Sporidesmium sclerotivorum macroconidia added to plot, and (iii) time of soil infestation with S. sclerotivorum. The cropping sequence was corn-soybean-soybean in 1996, 1997, 
and 1998, respectively, or soybean all three years in the plot areas. Sixteen plots at each site were infested at 2 spores per $\mathrm{cm}^{2}$, 20 spores per $\mathrm{cm}^{2}$, or left uninfested (control). Half of the infestations were made in fall 1995 after harvest, and the remaining half were made in spring 1996. Each experiment was a $2 \times 2 \times 3$ factorial with four replications in a nested randomized complete block design where spore concentration was nested within dates of soil infestation and dates of infestation were nested within crop rotation systems. Analysis of variance was conducted using the GLM procedure of the Statistical Analysis Systems (SAS Institute, Cary, NC). Main effects for cropping sequence, amount of inoculum added to each plot, and time of soil infestation were calculated and their means separated using the least significant difference test with a probability level of $P=0.05$.

Inoculum production and soil infestation. Sporidesmium sclerotivorum isolate CS-5, obtained from the USDA Biocontrol Laboratory at Beltsville, MD, was used for all field studies. It was incubated for about 10 weeks at $22^{\circ} \mathrm{C}$ with $12 \mathrm{~h}$ light daily in $125-\mathrm{ml}$ flasks containing $30 \mathrm{ml}$ of SM-4 medium and $3 \mathrm{~g}$ of vermiculite (8). The cultures were suspended in distilled water, ground in a Waring blender at high speed for $60 \mathrm{~s}$, and passed through 20 and 40 mesh sieves. Macroconidia concentration was measured with a hemacytometer, and calculations were made to adjust it with water to the volume and concentrations required for each treatment. Such spore suspensions were sprayed over the soil and crop residues at a rate of 560 liters/ha using a 14-liter backpack sprayer. The soybean residues and spores were incorporated into the top $5 \mathrm{~cm}$ of soil immediately after application of the mycoparasite, using a rototiller. Uninfested control plots were rototilled first to avoid interplot contamination.

Plot management. In 1996 and 1997, BSR 101, a soybean cultivar moderately resistant to SSR, was planted in all locations; in 1998, Asgrow 2242, a susceptible variety, was planted. Soybeans were planted with $38-\mathrm{cm}$ row widths at Humboldt and Kanawha and $19-\mathrm{cm}$ rows at Ames. Hybrid field corn was planted on $76-\mathrm{cm}$ row spacing at about 64,000 plants per ha in the experimental plots and in the border areas in all locations in 1996 and 1997. In 1998, the border areas were planted with the same soybean cultivar and planting density used in the experimental plots. At the end of the 1996 and 1997 seasons, soybean plants were mowed in situ, and the soybean residues remained on the plots. In 1998, soybeans were harvested with a plot combine and the yield was measured.

Weeds were controlled by hoeing in all three locations for the duration of the study. Special care was taken to avoid interplot contamination. Glyphosate (Roundup; Monsanto Co., St. Louis, MO) (2 $\mathrm{kg} / \mathrm{ha}$ ) was sprayed to control emerged weeds immediately after planting in 1996 and 1997. No herbicides were used in 1998.

Assessment of Sclerotinia activity. Disease incidence was estimated as the average percentage of plants showing visible symptoms of infection in three 1-m row lengths selected arbitrarily throughout each plot. The average number of apothecia and the number of carpogenically germinated sclerotia (sclerotia that produced apothecia) present in $1 \mathrm{~m}^{2}$ were estimated after rain events and continued every 7 days until no new apothecia were detected in the field.

Detection of Sporidesmium in soil. The presence of $S$. sclerotivorum was detected by baiting from soil samples collected from all plots and locations at the end of the 1996 and 1997 growing seasons. Twelve scoops of soil were arbitrarily taken with a hand-trowel from the top $5 \mathrm{~cm}$ of soil in each plot. Samples were blended and air-dried. Two subsamples per plot (approximately $30 \mathrm{~g}$ each) were placed in sterile glass petri dishes and baited with laboratory-produced Sclerotinia sclerotiorum sclerotia. Each dish was seeded with 10 sclerotia. Soil samples were moistened to about field capacity, sealed with Parafilm, and incubated for 4 weeks at room temperature in the dark.

Sclerotia retrieved by wet sieving were surface-disinfested in $0.5 \% \mathrm{NaOCl}$ for 1 min, rinsed in sterile distilled water, and placed on moist sterile filter paper in petri dishes. The dishes were sealed and incubated for 4 weeks at $20^{\circ} \mathrm{C}$ with 12 -h fluorescent light daily and were periodically observed microscopically for signs of $S$. sclerotivorum.

Macroplot experiments. Six commercial soybean fields severely affected with SSR were selected for macroplot experiments. The fields were located on north central Iowa farms near Conrad (two), Alexander, Nora Springs, Nashua, and Humboldt. The latter two sites were infested with S. sclerotivorum in spring 1996 and were planted to soybean in 1996 and 1998. The Nora Springs site and one Conrad site were infested in fall 1997, and the Alexander and second Conrad sites were infested in spring 1997. These four sites were planted to corn in 1997 and to soybean in 1998 .

Two macroplots of $100 \mathrm{~m}^{2}(10 \times 10 \mathrm{~m})$ were infested with macroconidia in each field, and the inoculum was incorporated to about $5 \mathrm{~cm}$ with a rototiller. The two macroplots were separated by at least 35 $\mathrm{m}$. Infestation rates were 20 macroconidia per $\mathrm{cm}^{2}$ for the Humboldt and Nashua macroplots and 100 macroconidia per $\mathrm{cm}^{2}$ for the other locations. Sclerotinia stem rot incidence was determined in 1998 in the macroplot area and in transects at 5, 10, 15, and $20 \mathrm{~m}$ from the infested plot boundaries in all cardinal directions. Readings made more than $20 \mathrm{~m}$ from the infested plots were considered to be representative of the disease incidence in the commercial field. Disease incidence was recorded as soon as SSR signs and symptoms were observed in the field and continued at 2-week intervals until crop maturity.

\section{RESULTS}

Sclerotinia activity. SSR epidemics developed in the second half of August in 1996 at the Humboldt and Kanawha sites. No epidemics were detected at the Ames site in this year. The incorporation of $S$. sclerotivorum resulted in a reduction $(P=$ $0.05)$ of SSR incidence within the first year at Humboldt (Table 1). Average disease incidence for $S$. sclerotivorum-infested plots was $<30 \%$ of the incidence for the controls. No differences were detected between infested and noninfested plots at Kanawha.

In 1998, plots infested with the highest concentration of $S$. sclerotivorum had 63 and $51 \%$ less disease $(P=0.05)$ than the control plots at Ames and Kanawha, re-

Table 1. Sclerotinia stem rot incidence in 1996 and 1998 in plots infested with two concentrations of Sporidesmium sclerotivorum macroconidia at three Iowa locations

\begin{tabular}{|c|c|c|c|c|c|c|}
\hline \multirow{3}{*}{$\begin{array}{l}\text { Infestation levels in } \\
\text { spores per } \mathrm{cm}^{2}\end{array}$} & \multicolumn{6}{|c|}{ Sclerotinia stem rot incidence (\%) } \\
\hline & \multicolumn{3}{|c|}{1996} & \multicolumn{3}{|c|}{1998} \\
\hline & Ames & Humboldt & Kanawha & Ames & Humboldt & Kanawha \\
\hline 0 & $\ldots^{\mathrm{a}}$ & 9.2 & 6.7 & 17.1 & 0.2 & 11.9 \\
\hline 2 & $\ldots$ & 1.8 & 6.7 & 9.5 & 0.3 & 6.2 \\
\hline 20 & $\ldots$ & 3.5 & 3.6 & 6.3 & 0.1 & 5.8 \\
\hline $\operatorname{LSD}(P=0.05)^{\mathrm{b}}$ & $\ldots$ & 3.4 & 9.9 & 6.5 & 0.4 & 3.8 \\
\hline
\end{tabular}

\footnotetext{
${ }^{a}$ No disease was detected in 1996.

${ }^{\mathrm{b}}$ Least significant difference. Values in columns are the mean of 16 observations.
} 
spectively (Table 1). The average SSR incidence in noninfested plots was 17 and $12 \%$ for Ames and Kanawha, respectively. No significant differences in disease incidence were detected between the 2 and 20 spores per $\mathrm{cm}^{2}$ rates of $S$. sclerotivorum macroconidia application. Very little SSR developed in the experimental area at Humboldt in 1998. However, the average SSR incidence $25 \mathrm{~m}$ into the surrounding commercial field planted on the same date, to the same variety, and with the same planting settings, was $17 \%$.

The magnitude of SSR epidemics that developed in 1996 at the Humboldt and Kanawha sites was not affected by the time of soil infestation with $S$. sclerotivorum (data not shown). The effect of crop sequence on SSR incidence could not be evaluated in 1997 at any location; high temperatures and dry conditions prevented the development of SSR epidemics. In 1998, there was no significant effect of crop sequence on SSR (data not shown).

Apothecia production. Infesting the soil with macroconidia of $S$. sclerotivorum number of carpogenically germinated sclerotia in 1996 at any location, but in 1998, significant differences among treatments were detected at all locations. In 1996, an did not have a significant impact on the

overall average of $0.2,2.8$, and 4.8 sclerotia per $\mathrm{m}^{2}$ produced apothecia at Ames, Humboldt, and Kanawha, respectively. In the 1998 season, plots infested with the highest concentration of $S$. sclerotivorum macroconidia had 55 and $57 \%$ fewer $(P=$ $0.05)$ carpogenically germinated sclerotia at Ames and Kanawha, respectively, compared with noninfested plots (Table 2). Ames plots infested with the highest concentration of $S$. sclerotivorum macroconidia had $42 \%$ fewer carpogenically germinated sclerotia than plots infested with the lower concentration $(P=0.05)$.

Significantly fewer apothecia per $\mathrm{m}^{2}(P$ $=0.05)$ were observed in infested plots, compared with noninfested plots, in 1996 and 1998. The first apothecia in 1996 were detected the first week of August at Ames and the third week of July at Humboldt and Kanawha in plots planted to corn. New apothecia were produced every week for the next 5 weeks at Humboldt, whereas at Kanawha, new apothecia were detected only during the third and fifth weeks after the first sighting. From 21 to $60 \%$ fewer apothecia were observed in plots infested with highest concentration of $S$. sclerotivorum macroconidia than in noninfested plots. Infestation with the higher rate of macroconidia resulted in 28 to $38 \%$

Table 2. Effect of soil infestation with two concentrations of Sporidesmium sclerotivorum macroconidia on the number of carpogenically germinated sclerotia and the number of apothecia of Sclerotinia sclerotiorum at three Iowa locations

\begin{tabular}{|c|c|c|c|c|c|}
\hline \multirow{2}{*}{$\begin{array}{l}\text { Infestation levels in } \\
\text { spores per } \mathrm{cm}^{2}\end{array}$} & \multicolumn{3}{|c|}{1996} & \multicolumn{2}{|c|}{$1998^{a}$} \\
\hline & Ames & Humboldt & Kanawha & Ames & Kanawha \\
\hline & \multicolumn{5}{|c|}{ Number of carpogenically germinated sclerotia per $\mathrm{m}^{2}$} \\
\hline 0 & 0.3 & 2.9 & 5.3 & 3.3 & 1.4 \\
\hline 2 & 0.2 & 3.1 & 5.2 & 2.6 & 0.7 \\
\hline 20 & 0.2 & 2.4 & 3.8 & 1.5 & 0.6 \\
\hline \multirow[t]{2}{*}{$\operatorname{LSD}^{\mathrm{b}}(P=0.05)$} & 0.3 & 1.4 & 1.6 & 0.5 & 0.5 \\
\hline & \multicolumn{5}{|c|}{ Number of apothecia per $\mathrm{m}^{2}$} \\
\hline 0 & 1.0 & 5.1 & 19.0 & 4.0 & 1.8 \\
\hline 2 & 0.5 & 6.5 & 16.9 & 5.6 & 0.8 \\
\hline 20 & 0.4 & 4.0 & 12.1 & 2.4 & 0.9 \\
\hline $\operatorname{LSD}(P=0.05)$ & 0.8 & 0.9 & 1.9 & 2.1 & 0.7 \\
\hline
\end{tabular}

${ }^{a}$ No apothecial production was observed at Humboldt in 1998.

${ }^{b}$ Least significant difference. Values in columns are the mean of 16 observations. fewer apothecia per $\mathrm{m}^{2}(P=0.05)$ than plots infested with 2 macroconidia per $\mathrm{cm}^{2}$ at Humboldt and Kanawha (Table 2). In 1998, Ames plots infested with the higher rate of macroconidia had an average of 2.4 apothecia per $\mathrm{m}^{2}$, significantly fewer apothecia than plots infested at the lower rate, but not significantly lower than the number of apothecia produced in noninfested control plots. The infested plots at Kanawha, regardless of infestation rate, had 50\% fewer apothecia than noninfested plots.

Fall soil infestation with $S$. sclerotivorum macroconidia resulted in 39 and $41 \%$ reductions $(P=0.1)$ in the number of carpogenically germinated sclerotia and the number of apothecia per $\mathrm{m}^{2}$ produced at Humboldt in 1996, respectively, compared with spring infestation. At the Kanawha site, in 1996, 16\% fewer carpogenically germinated sclerotia $(P=0.09)$ were observed in plots treated with $S$. sclerotivorum in the fall compared with spring infestation, but no significant differences were detected in the number of apothecia produced (Table 3). Timing of soil infestation did not affect the number of carpogenically germinated sclerotia or the number of apothecia produced at the Ames site in 1996. In 1998, Ames plots infested in the fall had $46 \%$ fewer carpogenically germinated sclerotia than plots infested in the spring, but no effect on the number of apothecia produced was detected.

In 1996, plots planted to corn had almost twice as many carpogenically germinated sclerotia per $\mathrm{m}^{2}$ and two to five times more apothecia per $\mathrm{m}^{2}(P=0.05)$ than plots planted to soybean at Humboldt and Kanawha (Table 3). In 1998, when all plots were planted to soybean, no differences were observed at any location. The Ames site produced on average four times more apothecia per meter than the Kanawha site. No apothecia were observed in the Humboldt plots in 1998 .

Sporidesmium activity in soil. At the end of 1996, the noninfested control plots at Ames had been contaminated with $S$. sclerotivorum. Almost $13 \%$ of the baits

Table 3. Effect of time of soil infestation with Sporidesmium sclerotivorum macroconidia and two cropping sequence systems on the number of carpogenically germinating sclerotia of Sclerotinia sclerotiorum at three Iowa locations

\begin{tabular}{|c|c|c|c|c|c|c|c|c|c|c|}
\hline \multirow[b]{3}{*}{ Factor } & \multicolumn{5}{|c|}{ Carpogenically germinated sclerotia per $\mathbf{m}^{2}$} & \multicolumn{5}{|c|}{ Number of apothecia per $\mathbf{m}^{2}$} \\
\hline & \multicolumn{3}{|c|}{1996} & \multicolumn{2}{|c|}{$1998^{\mathrm{a}}$} & \multicolumn{3}{|c|}{1996} & \multicolumn{2}{|c|}{1998} \\
\hline & Ames $^{b}$ & Humboldt & Kanawha & Ames & Kanawha & Ames & Humboldt & Kanawha & Ames & Kanawha \\
\hline \multicolumn{11}{|l|}{ Time of infestation } \\
\hline Fall 1995 & 0.3 & 2.1 & 4.4 & 1.7 & 0.8 & 0.6 & 4.0 & 15.4 & 5.1 & 1.2 \\
\hline Spring 1996 & 0.2 & 3.4 & 5.2 & 3.2 & 1.0 & 0.7 & 6.7 & 16.6 & 2.9 & 1.1 \\
\hline $\operatorname{LSD}^{\mathrm{c}}(P=0.05)$ & 0.2 & 1.3 & 0.8 & 1.1 & 0.5 & 0.7 & 2.7 & 2.5 & 3.5 & 0.6 \\
\hline \multicolumn{11}{|l|}{ Crop sequence ${ }^{\mathrm{d}}$} \\
\hline Soy-soy-soy & 0.2 & 2.2 & 4.7 & 2.7 & 1.1 & 0.5 & 2.2 & 10.4 & 4.0 & 0.9 \\
\hline Corn-soy-soy & 0.3 & 4.3 & 7.3 & 2.3 & 0.7 & 0.8 & 4.3 & 21.6 & 4.0 & 1.4 \\
\hline $\operatorname{LSD}(P=0.05)$ & 0.2 & 1.1 & 1.3 & 1.1 & 0.5 & 0.7 & 2.0 & 5.8 & 0.3 & 0.6 \\
\hline
\end{tabular}

${ }^{a}$ No apothecia were observed at Ames, Humboldt, and Kanawha in 1997 and in Humboldt in 1998.

${ }^{\mathrm{b}}$ Plots at Ames were reinfested in fall 1996 and spring 1997.

${ }^{c}$ Least significant difference. Values in columns are the mean of 24 observations.

${ }^{\mathrm{d}}$ Crop sequence planted in 1996, 1997, and 1998, respectively. All plots were planted to soybean in 1995. 
were colonized by the mycoparasite. At the end of the 1997 season, plots reinfested with the higher concentration of S. sclerotivorum had five times more baits colonized by $S$. sclerotivorum than noninfested plots (Table 4). Plots infested with 2 spores per $\mathrm{cm}^{2}$ had 2.7 -fold more sclerotial baits parasitized by $S$. sclerotivorum than noninfested (control) plots.

All control plots at Humboldt were heavily infested with the mycoparasite by the end of 1996. An average of $30 \%$ of the sclerotia baited to samples from these plots yielded Sporidesmium. No differences were detected between the lower and higher concentrations. By the end of 1997 , the overall average of colonized sclerotia was $35 \%$, and no differences were detected among the levels of initial infestation.

Kanawha was the only experimental site where noninfested control plots remained essentially free of detectable $S$. sclerotivorum through fall 1997 . The rate of bait infection related directly to the amount of $S$. sclerotivorum macroconidia originally infested into the plots. Plots infested with 20 spores per $\mathrm{cm}^{2}$ of soil yielded almost 1.5 times more $(P=0.05)$ infected sclerotial baits than sclerotia baited to samples from plots infested with 2 spores per $\mathrm{cm}^{2}$. Cropping sequence and fall versus spring macroconidia infestation had no effect on the rate of $S$. sclerotivorum recovery by baiting, regardless of the experimental site and year (data not presented).

Macroplot experiments. SSR epidemics developed in 1998 at five of the six locations. Nashua had no epidemics because weather conditions were not conducive for disease development. In four of these five experiments, significant reduc- tions in SSR incidence, ranging from 56 to $100 \%$, were detected in relation to the average incidence over $20 \mathrm{~m}$ beyond the infested area in the commercial fields (Table 5). Disease incidence $5 \mathrm{~m}$ beyond the border of infestation at Conrad 1 and Humboldt fields was no different from the incidence of SSR observed within the macroplot. But the incidence of SSR at 5 $\mathrm{m}$ from the infested areas at these two sites was significantly less than that observed 10 $\mathrm{m}$ from the edge of the infested area (Table 5). Average SSR incidence at Alexander and Nora Springs was significantly lower within the infested area than $5 \mathrm{~m}$ beyond the border of infestation. The incidence of SSR 15 and $20 \mathrm{~m}$ beyond the border of the area infested with $S$. sclerotivorum macroconidia was essentially the same as any readings made $20 \mathrm{~m}$ beyond the macroplot borders.

\section{DISCUSSION}

S. sclerotivorum provided effective SSR control, ranging from 51 to $100 \%, 2$ years after its incorporation into the soil at all factorial experiments, and at four of the six macroplots established in farmers' fields. Two years after infestation with 20 macroconidia per $\mathrm{cm}^{2}$, the macroplots at Humboldt were disease free; yet the areas $>20$ $\mathrm{m}$ beyond the plots had an SSR incidence of $17 \%$. A similar situation was observed in macroplots established at Conrad (site 1), Nora Springs, and Alexander. The same time frame to achieve significant control levels has been observed by other researchers working with S. sclerotivorum on control of Sclerotinia minor in lettuce (5).

The experimental area at Humboldt showcased the potential of S. sclerotivorum as a biological control agent of Sclerotinia sclerotiorum. This site was selected because it had a history of high incidence of Sclerotinia stem rot. Nonetheless, the Humboldt site was the only instance where a significant reduction in disease incidence was observed in the season following soil infestation. In 1998, only traces of SSR were observed within the nearly $1,500 \mathrm{~m}^{2}$ experimental area; yet outside of the experimental area in the same field, the SSR incidence was $17 \%$. The extra food produced by supplementing these plots with more sclerotia, and the more acidic soil conditions at Humboldt ( $\mathrm{pH}$ 6.4), may have stimulated $S$. sclerotivorum parasitic activity (9). The availability of native sclerotia in the buffer areas, and the effect of the heavy rains of 1996, may have also facilitated the spread of $S$. sclerotivorum into noninfested areas. Although S. sclerotivorum has been detected in other areas of the state (16), any indigenous populations of the mycoparasite in the experimental field were either absent or at an undetectably low level because $S$. sclerotivorum was not retrieved from soil samples from the commercial fields surrounding the experimental area at Humboldt.

The aggregated pattern and high sclerotial population densities of Sclerotinia minor in the soil have been mentioned as important factors contributing to the fast spread of $S$. sclerotivorum in the soil (5). Sclerotinia sclerotiorum sclerotia can also be aggregated in the soil (13), but its population densities are usually significantly lower than the ones reported for Sclerotinia minor (12). In this study, the more uniform distribution of sclerotia, and the considerably larger sclerotial mass of Sclerotinia

Table 4. Percentage of sclerotia of Sclerotinia sclerotiorum colonized by Sporidesmium sclerotivorum after 4 weeks incubation in soils from three Iowa locations, previously infested with two concentrations of Sporidesmium sclerotivorum macroconidia

\begin{tabular}{|c|c|c|c|c|c|c|}
\hline \multirow{3}{*}{$\begin{array}{l}\text { Infestation levels in } \\
\text { spores per } \mathrm{cm}^{2}\end{array}$} & \multicolumn{6}{|c|}{ Percentage of sclerotial baits colonized by $S$. sclerotivorum } \\
\hline & \multicolumn{2}{|c|}{ Ames } & \multicolumn{2}{|c|}{ Humboldt } & \multicolumn{2}{|c|}{ Kanawha } \\
\hline & 1996 & 1997 & 1996 & 1997 & 1996 & 1997 \\
\hline 0 & 12.8 & 5.1 & 30.3 & 38.3 & 0.4 & 0.0 \\
\hline 2 & 5.7 & 13.9 & 19.1 & 33.3 & 11.2 & 20.4 \\
\hline 20 & 11.3 & 25.8 & 36.1 & 35.2 & 18.1 & 30.5 \\
\hline $\operatorname{LSD}(P=0.05)^{\mathrm{a}}$ & 10.2 & 5.3 & 20.3 & 7.2 & 2.4 & 8.5 \\
\hline
\end{tabular}

${ }^{a}$ Least significant difference. Values in columns are the mean of 16 observations.

Table 5. Incidence of Sclerotinia stem rot in commercial soybean fields in 1998 where $100 \mathrm{~m}^{2}$ plots were infested with macroconidia of Sporidesmium sclerotivorum 1 or 2 years earlier

\begin{tabular}{|c|c|c|c|c|c|c|}
\hline \multirow[b]{3}{*}{ Location } & \multirow{3}{*}{$\begin{array}{l}\text { Time of } \\
\text { infestation }\end{array}$} & \multicolumn{4}{|c|}{ Sclerotinia stem rot incidence (\%) } & \multirow[b]{3}{*}{$\operatorname{LSD}^{\mathbf{b}}(P=\mathbf{0 . 0 5})$} \\
\hline & & \multicolumn{3}{|c|}{ Distance in meters from infested area } & \multirow[b]{2}{*}{ Commercial field $^{a}$} & \\
\hline & & $\mathbf{0}$ & 5 & 10 & & \\
\hline Conrad 1 & Fall 96 & 0.0 & 0.7 & 5.8 & 5.6 & 2.2 \\
\hline Nora Springs & Fall 96 & 3.1 & 7.1 & 7.0 & 7.1 & 1.3 \\
\hline Humboldt & Spring 96 & 0.0 & 2.7 & 10.8 & 15.0 & 6.1 \\
\hline Nashua & Spring 96 & 0.0 & 0.0 & 0.0 & 0.2 & 0.2 \\
\hline Alexander & Spring 97 & 1.1 & 7.6 & 11.6 & 10.5 & 2.5 \\
\hline Conrad 2 & Spring 97 & 7.3 & 9.2 & 9.0 & 9.0 & 2.3 \\
\hline
\end{tabular}

a Sclerotinia stem rot incidence in areas greater than $20 \mathrm{~m}$ from borders of infested macroplots.

${ }^{\mathrm{b}}$ Least significant difference. Values in rows are the mean of four observations. 
sclerotiorum sclerotia, may have played an important role in the rapid colonization of soil by S. sclerotivorum. Larger sclerotial bodies may provide more energy than smaller sclerotia to support growth of mycoparasites (25), which could result in better coverage of the area surrounding an infected sclerotium.

Fall application of the mycoparasite resulted in fewer carpogenically germinated sclerotia at Humboldt and Kanawha in the season following the soil infestation than spring application. This difference disappeared by 1998 . It seems logical that earlier soil infestation will provide more time for the mycoparasite to become established in the soil, thereby increasing the possibility of significant reductions of disease incidence in the following season. According to Stolk et al. (25), once the parasite is established in the soil, the most important factor driving the growth of the population is the availability of food rather than the concentration at which the parasite is present at the beginning of the season. In many instances in this study, infesting 2 macroconidia per $\mathrm{cm}^{2}$ of soil appeared to be equal in effectiveness to adding 20 macroconidia per $\mathrm{cm}^{2}$. Availability of a sclerotial food source and thorough mixing of the soil may have been more important than dosage of the biocontrol agent.

The benefit of rotating soybean with a nonalternate host, such as corn, could not be determined in this study in 1997. However, it is evident that S. sclerotivorum requires more than one season to significantly impact the sclerotial population in the soil. Planting corn provided such additional time without the risk of replenishing the sclerotial bank in the soil. Further, apothecia were detected earlier in plots planted to corn at all three locations than in plots planted to soybean. It is possible that environmental conditions favorable for apothecia production are present longer under the corn canopy than under the soybean canopy, resulting in earlier and more thorough depletion of the sclerotial bank.

Although soil infestation with $S$. sclerotivorum was associated with significant reductions in the number of sclerotia producing apothecia, number of apothecia produced, and the reduction in SSR incidence in the 1998 season, no significant yield reductions were detected among treatments at any location. SSR developed late in the season in 1998, and the incidence was $20 \%$ or less, making it unlikely that $S$. sclerotiorum would have a yield impact.

The detection of what seemed to be a disease gradient 5 to $10 \mathrm{~m}$ away from the macroplots at almost all locations confirms our suspicion that, in order to detect yield differences among treatments and reduce interplot interference, plots larger than the ones used in the factorial experiments will be required. The $100 \mathrm{~m}^{2}$ macroplots we used may not be adequate if large numbers of ascospores can be transported up to 80 $\mathrm{m}$, as demonstrated by Wegulo et al. (27).

The potential of $S$. sclerotivorum as a biocontrol agent for Sclerotinia stem rot of soybean was demonstrated in this study. However, there are some limitations to its development as a commercially applied biocontrol agent. The most obvious limitation is the lack of a procedure to produce commercial quantities of inoculum of the mycoparasite. S. sclerotivorum is very fastidious to grow in artificial media, and its macroconidia will germinate only in the presence of host sclerotia (23). The inoculum used in these studies was produced in SM-4 medium (8). This medium yielded $1.11 \times 10^{5}$ macroconidia per $\mathrm{g}$ of wet medium after 10 weeks of incubation instead of the $10^{6}$ spores per g estimated by Adams and Fravel (5). Perhaps a longer incubation time may result in a higher yield, but at the present rate, it would be necessary to produce $18 \mathrm{~kg}$ of inoculum to infest 1 ha at 20 macroconidia per $\mathrm{cm}^{2}$. If the 2 spores per $\mathrm{cm}^{2}$ rate would be adequate, this would reduce inoculum requirements to $1.8 \mathrm{~kg} / \mathrm{ha}$. Should it be possible to produce $10^{6}$ macroconidia per $\mathrm{g}$ of medium, 1 ha could be infested at the 2 spores per $\mathrm{cm}^{2}$ level with only seven 125 -ml flasks of inoculum. Production of toxicological data on S. sclerotivorum is also required (20) before this organism is approved for commercialization.

Two outstanding traits associated with $S$. sclerotivorum may ironically harm its chances of being commercially developed. The fungus is a very aggressive colonizer of sclerotia in soil (19) and produces numerous new macroconidia on the sclerotia (6). This uniqueness allows the parasite to remain active for a few years after a single infestation event (21), a trait that may not foster repeat customers.

\section{ACKNOWLEDGMENTS}

Journal Paper No. J-19416 of the Iowa Agriculture and Home Economics Experiment Station, Ames, IA, Project No. 2405, and supported by Hatch Act and State of Iowa funds. Portion of a Ph.D. dissertation by the first author submitted to the Graduate College, Iowa State University. This research was funded in part by the Leopold Center for Sustainable Agriculture and the Iowa Soybean Promotion Board.

\section{LITERATURE CITED}

1. Abawi, G. S., and Grogan, R. G. 1975. Source of primary inoculum and effects of temperature and moisture on infection of beans by Whetzelinia sclerotiorum. Phytopathology 65:300-309.

2. Adams, P. B. 1989. Comparison of antagonists of Sclerotinia species. Phytopathology 79:1345-1347.

3. Adams, P. B., and Ayers, W. A. 1979. Ecology of Sclerotinia species. Phytopathology 69:896-899.

4. Adams, P. B., and Ayers, W. A. 1982. Biological control of Sclerotinia lettuce drop in the field by Sporidesmium sclerotivorum. Phytopathology 72:485-488.

5. Adams, P. B., and Fravel, D. R. 1990. Economical biological control of Sclerotinia let- tuce drop by Sporidesmium sclerotivorum Phytopathology 80:1120-1124.

6. Adams, P. B., Marois, J. J., and Ayers, W. A 1984. Population dynamics of the mycoparasite Sporidesmium sclerotivorum, and its host, Sclerotinia minor in soil. Soil Biol. Biochem. 16:627-633.

7. Adams, P. B., and Tate, C. J. 1976. Mycelial germination of sclerotia of Sclerotinia scle rotiorum on soil. Plant Dis. Rep. 60:515-518.

8. Ayers, W. A., and Adams, P. B. 1983. Improved media for growth and sporulation of Sporidesmium sclerotivorum. Can. J. Microbiol. 29:325-330.

9. Ayers, W. A., Barnett, E. A., and Adams, P. B 1981. Germination of macroconidia and growth of Sporidesmium sclerotivorum in vitro. Can. J. Microbiol. 27:664-669.

10. Bedi, K. S. 1963. The age and size of the sclerotia of Sclerotinia sclerotiorum (Lib.) de Bary in relation to the formation of apothecia. J. Ind. Bot. Soc. 42:204-207.

11. Boland, G. J., and Hall, R. 1988. Epidemiology of Sclerotinia stem rot of soybean in Ontario. Phytopathology 78:1241-1245.

12. Boland, G. J., and Hall, R. 1988. Numbers and distribution of apothecia of Sclerotinia sclerotiorum in relation to white mold of white bean (Phaseolus vulgaris). Can. J. Bot. 66:247-252.

13. Boland, G. J., and Hall, R. 1988. Relationships between the spatial pattern and number of apothecia of Sclerotinia sclerotiorum and stem rot of soybean. Plant Pathol. 37:329336.

14. Chamberlain, D. W. 1951. Sclerotinia stem rot of soybeans. Plant Dis. Rep. 35:490-491.

15. Coley-Smith, J. R., and Cooke, R. C. 1971 Survival and germination of fungal sclerotia. Annu. Rev. Phytopathol. 9:65-92.

16. del Rio, L., Martinson, C. A., Yang, X. B., and Tiffany, L. H. 1998. Characterization of micoflora parasitic to sclerotia of Sclerotinia sclerotiorum in Iowa. Phytopathology 88:S115.

17. Fravel, D. R. 1998. Use of Sporidesmium sclerotivorum for biocontrol of sclerotial plant pathogens. Pages 37-47 in: PlantMicrobe Interactions and Biological Control. G. J. Boland and L. D. Kuykendall, eds. Marcel Dekker, New York.

18. Grau, C. 1988. Sclerotinia stem rot of soybean. Pages 56-66 in: Soybean Diseases of the North Central Region. T. D. Wyllie and D. H. Scott, eds. American Phytopathological Society, St. Paul, MN.

19. Gulya, T. J., Adams, P. B., and Rashid, K. Y. 1992. Natural biocontrol of Sclerotinia sclerotiorum in sunflower. Pages 73-74 in: Proc. Sunflower Res. Workshop, 14th. Natl. Sunflower Assoc., Bismarck, ND.

20. Lemaire, J. M., Alabouvette, C., Davet, P. and Tramier, R. 1986. Problems posed by the large scale application of microorganisms for biological control of soil-borne plant pathogens. Symbiosis 2:287-301.

21. Martinson, C. A., and del Rio, L. E. 2001 Prolonged control of Sclerotinia sclerotiorum with Sporidesmium sclerotivorum. Pages 133134 in: Proc. XI Int. Sclerotinia Workshop. York, UK.

22. Mischke, S. 1998. Mycoparasitism of selected sclerotia-forming fungi by Sporidesmium sclerotivorum. Can. J. Bot. 76:460-466.

23. Mischke, S., Mischke, C. F., and Adams, P. B. 1995. A rind-associated factor from sclerotia of Sclerotinia minor stimulates germination of a mycoparasite. Mycol. Res. 99:1063 1070 .

24. Schwartz, H. F., and Steadman, J. R. 1978. Factors affecting sclerotium populations of and apothecium production by, Sclerotinia sclerotiorum. Phytopathology 68:383-388. 
25. Stolk, C., van den Bosch, F., Termorshuizen, A. J., and Jeger, M. J. 1998. Modeling the dynamics of a fungal mycoparasite and its host: An energy-based approach. Phytopathology 88:481-489.

26. Uecker, F. A., Ayers, W. A., and Adams, P. B. 1978. A new Hyphomycete on sclerotia of Sclerotinia sclerotiorum. Mycotaxon 7:275282.
27. Wegulo, S. N., Sun, P., Martinson, C. A., and Yang, X. B. 2000. Spread of sclerotinia stem rot of soybean from area and point sources of apothecial inoculum. Can. J. Plant Sci. 80:389-402.

28. Willets, H. J., and Wong, J. A. L. 1980. The biology of Sclerotinia sclerotiorum, S. trifoliorum, and $S$. minor with emphasis on specific nomenclature. Bot. Rev. 46:101-165.
29. Wrather, J. A. 1998. Yield-robbing soybean diseases. Proc. 1998 Midwest Soybean Conf Des Moines, IA.

30. Wrather, J. A., Anderson, T. R., Arsyad, D. M., Gai, J., Ploper, L. D., Porta-Puglia, A. Ram, H. H., and Yorinori, J. T. 1997. Soybean disease loss estimates for the top 10 soybean producing countries in 1994. Plant Dis. 81:107-110. 